\title{
How do you wish to be cited? Citation practices and a scholarly community of care in trans studies research articles
}

\author{
Katja Thieme ${ }^{a,}{ }^{*}$, Mary Ann S. Saunders ${ }^{b}$ \\ ${ }^{a}$ Arts Studies in Research and Writing, Vantage College, Department of English Language and Literatures, University of British Columbia, \\ Vancouver, Canada \\ ${ }^{\mathrm{b}}$ Arts Studies in Research and Writing, University of British Columbia, Vancouver, Canada
}

\section{A R T I C L E I N F O}

\section{Article history:}

Available online 28 March 2018

\section{Keywords:}

Trans studies

Community of care

Citation

Erasure

Outing

Gender

Social justice

\begin{abstract}
A B S T R A C T
Trans rights advocacy is a social justice movement that is transforming language practices relating to gender. Research has highlighted the fact that language which constructs gender as binary harms trans people, and some trans studies researchers have developed guidelines for honouring trans people's names and pronouns. The language of academic writing is an area of discussion where questions of trans rights and trans experiences have not yet been addressed. This paper draws on two data sources to explore the citation experiences and practices of trans scholars and activists: a web-based archive of writers' perspectives built between 2015 and 2016; and a corpus-based study of 14 research articles published in TSQ: Transgender Studies Quarterly. Our analysis highlights the sensitivity that is required of colleagues who work with transgender authors' writing, furthering our understanding of citation as a collaborative and potentially intimate and caring practice. Practices of referring to work by trans scholars pose ethical questions about the social relations expressed in citation in general, enabling applied language scholars to develop a new and different awareness of the sociality of citation.
\end{abstract}

(c) 2018 Elsevier Ltd. All rights reserved.

Transsexual monstrosity, however, along with its affect, transgender rage, can never claim quite so secure a means of resistance because of the inability of language to represent the transgendered subject's movement over time between stably gendered positions in a linguistic structure.

\section{—Susan Stryker, "My Words to Victor Frankenstein”}

I feel I am constantly being asked to pick a team, stick to it, tick a box, choose F or M, make up your mind because you can't have it both ways ... But in my experience, there are more options than male or female, masculine or feminine. The meanings of these words change depending on the context, anyway, so my mutability is echoed in language. Is it possible to understand both language and myself as incoherent? As always spilling over the edges of intelligibility?

\footnotetext{
* Corresponding author.

E-mail address: Katja.Thieme@ubc.ca (K. Thieme).
} 


\section{Introduction}

Transgender studies is an interdisciplinary research field which first emerged in the 1990s, rapidly taking shape in the current century. Susan Stryker, a central figure in the field, has remarked that "what began with the efforts of emerging and marginally situated scholars and activists ... to be taken seriously on our own terms, and not pathologized and dismissed, has helped foster a sea-change in the academic study of gender, sex, sexuality, identity, desire, and embodiment" (Stryker, 2006, p. 2). The term transgender (often abbreviated as "trans") is a broad term used in reference to anyone who finds that the gender they were assigned at birth either incorrectly or inadequately accounts for how they experience their gender identity (conceptually broad, "transgender" comprises within it many identity categories). "Trans" stands in contrast to "cisgender" which refers to people who remain with the gender they were assigned at birth. The Latin prefix cis- ("on the same side as") is the corollary of trans- ("across") (Aultman, 2014; Enke, 2013).

During the time in which we worked on this paper, both authors attended "Trans*Studies: An International Transdisciplinary Conference on Gender, Embodiment, and Sexuality," the 2016 inaugural conference of the University of Arizona's Transgender Studies Initiative. The conference featured over 250 papers and its most remarkable feature was the sheer number of trans-identified scholars from different countries. Importantly, one of the keynote speakers was Sandy Stone, whose essay “The 'Empire' Strikes Back: A Posttranssexual Manifesto," written in the late 1980s and first published in 1991, is now widely recognized as the text from which contemporary transgender studies emerged (Stone, 1991). At the conference's closing party, Stone put her arm around one of the current authors and gestured to the room, saying "Look at all of us. Who could have imagined this 25 years ago?" She was taking note of an extraordinary community which has insisted on making knowledge about trans people and trans lives in the face of, at best, institutional indifference, but more often hostility, in the decades since the publication of her important essay. Our paper is about the role which citation practices, and attitudes towards citation, play in creating and sustaining the scholarly community of care which so moved Stone. The term "community of care" has been used in discussions of restorative justice (Bolivar, 2012), medical care (Epstein, Fiscella, Lesser, \& Stange, 2010), as well as teaching (Northedge, 2003; Owens \& Ennis, 2005; Ellerbrock \& Kiefer, 2010; see Tuck, 2018). In contrast to the broader concept of the academic community, we here propose the narrower concept of scholarly community of care to describe the closer relations among marginalized scholars that vitally sustain their ability to work within dominant systems (McCold, 2004).

Trans rights advocacy as a social justice movement is transforming current conversations about gender on many North American campuses. Trans activism pinpoints exclusions that cisgender people are not able to see and shows up forms of violence that many cisgender people are often unwilling to acknowledge. There are an increasing number of initiatives to get instructors and students to honour trans people's names and pronouns (The Social Justice Institute, n.d.); there are analyses of how violence against trans people impacts learning (Bilodeau, 2005; Rankin, 2005); there are demands to meet the unique on-campus needs of trans students and instructors (Krum, Davis, \& Galupo, 2013). While it might be expected that some of the drive towards discursive inclusiveness in postsecondary teaching will also have an effect on research writing, so far there has not been any discussion of questions of trans scholarship and trans experience in the realm of writing studies. As yet no research exists on the inclusion and discursive positioning of trans scholars in research writing. In Part I of this article, we explore the nuanced points that trans scholars have made about citation practices, drawing on a web-based archive built between 2015 and 2016 of statements by trans scholars and activists. In Part II, we offer an analysis of citation practices by trans scholars drawing on a corpus-based study of 14 research articles published in TSQ: Transgender Studies Quarterly.

\section{The research article, citation, and gender}

The contemporary research article is a relatively stable genre with a strong core or macro structure evidenced in textual practices across many disciplinary, rhetorical, linguistic and cultural contexts (often referred to as IMRAD-introduction, methods, results, and discussion). At the same time, research articles exhibit many documented differences at the micro level, that is at the level of phrase, sentence, paragraph or "steps" and "moves" (for useful recent overview of the challenges of mapping such stability and variation, see van Enk \& Power, 2017, and Moreno \& Swales, 2018; for variation according to disciplinary norms and practices see Hyland, 1999).

In the context of a high degree of stability alongside variability, our paper focusses on citation as a nearly universal characteristic of the contemporary research article, a "constitutive feature" of the genre (Hyland, 1999, p. 343). To the extent that it is a widely taken for granted academic textual practice, citation can offer appear, as one source in our archive puts it, as "objective and value neutral" (Dobrowolsky, 2013a). However, a number of studies have shown that citation practices are far from neutral and tend to reproduce a range of hierarchical relations, including male/female hierarchies. Quantitative research has been able to show that female scholars are underrepresented in citation counts (Davenport \& Snyder, 1995); that even when other factors are equal, male faculty have a higher likelihood to be highly cited (Toutkoushian, 1994); that where raw publication counts are equal, women across the natural sciences, social sciences, and humanities are less likely to be in the prestigious first author position (West, Jacquet, King, Correll, \& Bergstrom, 2013); and that as citations of women's publications increase, this increase tends to occur within articles by other women with male scholars not citing women at the increased rate in which they have entered a field (Lutz, 1990; McElhinny, Hols, Holtzkener, Unger, \& Hicks, 2003; see Nygaard and Bahgat, 2018). Much as they are able to reveal about gendered patterns of citation, such studies bear the flaw that they base their quantitative work on a stable and exclusively binary model of gender identity, working with the assumption that 
authors are neatly dividable into male and female categories, even as ambiguities in the use of first names and initials are noted.

Gender, however, is not a binary. The presence of transgender and non-binary scholars is not amenable to simple kinds of quantification, and not only because these scholars are often invisible as trans and non-binary persons to their readers. Transgender and non-binary scholars are almost always in an invisible minority in their discipline-sometimes to the point of producing "undisciplined knowledge" that is often disqualified and deemed irrelevant by those with disciplinary authority (Halberstam, 2011, p. 10). In addition, transgender is a category which, in David Valentine's words, is both plastic and collective, a category which includes "all and any kind of gender-variant identity and behavior" and the definition of which changes with the perspective of those who use it (Valentine, 2012, p. 201). That plasticity makes it a rather "unusable category" for studies that attempt to "count, measure, operationalize, define, or generate empirical data" (Labuski \& KeoMeier, 2015, p. 18). However, we suggest that trans scholars are in the process of developing unique community practices that result in distinctive questioning about how their work can and might be cited and thus probes our understanding of citation practices more generally.

\section{Method}

This paper draws on two interrelated studies. In Part I, we explore the experiences of transgender authors in academic contexts as they themselves have publicly described those experiences. We do so through analysis of an archive of online writing by mostly North American trans authors consisting of 54 items by 45 different authors which we collected between September 2015 and September 2016 through systematic internet searches as well as focussed attention to article links circulated by trans academics and activists on social media platforms (Facebook and Twitter). This archive contains articles, opinion pieces, blog posts, statements, and public social media posts by Canadian and US American trans scholars, artists, and activists. We identified sections in these pieces where authors discuss scholarly self-representation, their perspectives on how cisgender writers represent trans scholars, as well as their sense of inclusion and exclusion in various disciplines. Our analytic approach involved a method of "close reading" (Love, 2010) in order to summarize, as a form of rich context, the experiences described by the various trans authors in this archive. The goal of this interpretive work is to highlight not only trans scholars' concerns related to practices of citation but also their suggestions for alternative practices.

These concerns and practices that we outline in Part I of this paper frame the interpretation of the small-scale corpus analysis in Part II. In our analysis in Part II, we examine how cited trans authors are introduced in a corpus of 14 articles from the journal TSQ: Transgender Studies Quarterly, founded in 2014. TSQ is a research journal that functions as a community venue for trans scholarship; we therefore explore the extent to which it represents published praxis of the nuanced concerns that we lay out in our close reading of the texts of our archive in Part I. The aim of both parts of this paper is to explore how the practices of referring to work by trans scholars pose ethical questions about the social relations expressed in citation in general, enabling applied linguistics and writing scholars to develop a more enhanced awareness of the sociality of citation.

\section{Part I. Trans writers' public statements on citation}

Our overall approach involves heeding what Talia Mae Bettcher calls first-person authority of trans people over their own gendered experience (Bettcher, 2009). Thus, Part I foregrounds their perspectives, particularly the dynamics of erasure and outing as being of central concern. The writers of the materials in our assembled archive are scholars in a broad sense: some have teaching or research positions in higher education, some are graduate students, and some have academic training but are engaged in doing research in a non-academic capacity. There are generational differences to be considered between early and mid-career scholars, and between transitioning at differing life stages. The writers also differ in their choices between maintaining stricter privacy and making themselves visible (and potentially vulnerable) in public media spaces as trans scholars.

Given that previous studies on gender and citation have demonstrated that citation practices tend to reproduce male/ female hierarchies, we can expect citation to similarly reproduce cisgender hierarchies. As many trans writers in our archive point out, within cisnormative academic culture these hierarchies are invisible to most researchers, teachers and administrators, even as they are enforced by institutional systems and practices (Beemyn, 2015; Drmay, 2016; Hager, 2015; Spade, 2010, 2012; Wood \& Drmay, 2016). Trans scholars in our archive are acutely aware of such hierarchies. Given such awareness, it is important to investigate how the trans scholars in our archive position themselves within the academy, which leads into considerations of how citation and other bibliographic practices both place constraints on their full participation while also providing opportunities for the development of community among trans scholars.

\subsection{Against erasure}

The spectrum of constraints that is experienced by trans people when entering and participating in the academy can be theorized through the concept of “erasure." In her ground-breaking book Invisible Lives, sociologist Vivian K. Namaste defines trans erasure as, in part, "a conceptualization of gender that excludes the bodies and experiences of transsexual and transgendered [sic] people, and that informs the taken-for-granted work of institutions. 'Erasure' refers to the conceptual and institutional relations through which transsexual and transgendered [sic] people disappear from view” (Namaste, 2000, p. 
137). Focussing on the relationship between trans people and social service agencies, Namaste observes that institutional policies governing these agencies have not typically imagined the possibility of transgender clients and therefore are frequently not able to meet the unique needs of such populations. Namaste may not be talking about the institution of the academy, but her observations are nevertheless true of the academy: trans scholars in our archive document the "taken-forgranted work" of academic institutions which contributes on a broad scale to the erasure of trans people within them, such as the limited availability of safe and appropriate housing and facilities (Adams, 2015; Hager, 2015; Matsuda, 2015), and the inability of university registration systems to accommodate people whose lived experience of gender is not consistent with the gender they were assigned at birth (Adams, 2015; Beemyn, 2015; Howard, 2015). One author in our archive, Faughn Adams, a genderqueer clinical psychologist, notes that having a sense that one belongs is connected to psychological health, but developing such a sense of belonging is very difficult "in a system where you are constantly reminded that you don't actually belong" (Adams, 2015). Taking institutional erasure into account makes concrete what is at stake in citation practices, demonstrating how citation is but one piece in a larger set of institutional norms and practices. Shayle Matsuda, a biologist and trans author in our archive, observes that the absence of appropriate resources (e.g., trans-specific health care provisions) and institutional awareness (e.g., trans inclusion policies) tacitly enables both discrimination and ignorance, and such absence contributes to trans erasure within institutions (Matsuda, 2015). Matsuda's point reminds us as applied linguistics scholars that we need to take the prevalence and violence of these kinds of institutional erasure into account when considering the extent to which trans scholars are not present in certain fields, or are not present in a visible way through their publications.

In her blog Feministkilljoys (a frequently referenced piece in the online discussions we followed), Sara Ahmed writes about how the persistent institutional structures that continue to stabilize academia as a place for white men are the same structures that favour the over-representation of white, male authors in citations, thus erasing other voices (Ahmed, 2014). However, the cisgender nature of gendered, racial and heteronormative hierarchies is something that continues to be invisible to those who benefit from it; that is, to the vast majority of members of academia. As a queer woman of colour, Ahmed writes that through the white, male "lines people have already taken" other possibilities of citation are given up, which means "giving up on certain futures" (Ahmed, 2006, p. 183). Ahmed's point can be extended to observe that trans futures are being given up in similar ways, the futures of trans scholars already around us and of trans scholars who are not yet here. Ahmed suggests the countermeasure of highly activist practices of citation and explains in her blog (Ahmed, 2015) the "citation policy" she imposed on herself in the writing of her most recent book, Living a Feminist Life (Ahmed, 2017). For that book, she decided to no longer follow the citational lines that favour male theorists, and simply refused to include these scholars in the citations in her book.

In another text on our archive, Canadian trans writer Casey Plett demonstrates the power of such an approach for trans research and activism by, in effect, pitting transgender voices against cisgender voices in a critique of the violence that psychiatric paternalism continues to exert over many trans lives (Plett, 2016). Plett notes that mainstream media in North America has a tendency to characterize certain trans-affirming therapies as "controversial" on the strength of outdated research to which a small number of clinicians cling. Plett then asks, "what happens if you tried to leave the cis people out" of this conversation? In the spirit of Ahmed's citational policy, Plett's article features a powerful section where she cites only trans researchers and writers to present published critique of transphobic forms of therapy, concluding that "in 2016 it is unacceptable for anyone writing about this to suggest [that the affirming therapies in question are] 'controversial' or there is a 'debate'-it is cis people having this debate and it is cis people considering it controversial” (Plett, 2016). For Ahmed, a willful practice of citing otherwise, as Plett does, is a community-building practice, the practice of building shelters in a hostile world: "I often think of books as houses. They are built out of stuff. They create room for us to dwell. And I think of citations as bricks. When citations become habits, bricks form walls" (Ahmed, 2015). Plett shows the way to building similar shelters for trans people in which it is crucial for trans scholars to forge, willfully, their own lines of citation which challenge not just the violence of psychiatric paternalism but the cisnormativity of the academy as a whole.

Dobrowolsky issues a similar call, representing citation as a world-making tool which can be used in the service of social justice and social change. Noting that those who are in the position of being able to cite possess great privilege, she refers to their responsibility to therefore bring forward voices which might otherwise not be heard, and to ensure that voices which might be erased are not. "There is," she writes, "no excuse to not promiscuously link, footnote, or otherwise reference others' material” (Dobrowolsky, 2013d). Like Ahmed, she writes about the importance of acknowledging intellectual lineages which break from traditional lines of citation, suggesting that this is, over time, the way to remake the academy. As Dobrowolsky's and Plett's arguments show, making space for trans scholarship through citation is an important tool in combatting the ongoing erasure of trans persons. Since effective change of institutions requires its participants to listen carefully to the experiences of those who are under erasure, such citational practice involves making trans experience visible. However, enabling this visibility through citation comes with its own dangers, carrying the possibility of outing trans writers and their experience in ways they do not desire or that make them unsafe, a key theme of the texts in our archive.

\subsection{Against outing}

Institutional erasure ironically contributes to unlooked for and undesirable forms of trans visibility. Specifically, institutional erasure creates conditions under which trans people are "outed"-revealed to be trans-without their consent. For example, sources in our archive explain how registration and attendance procedures and the ways these are carried out by instructors may result in the unwanted outing of transgender people (Adams, 2015; Beemyn, 2015; Pryor, 2015; Spade, 2010). 
In this way, seemingly neutral student records deny trans people's agency-they lose control over whether or not to disclose that they are transgender, and to whom-which puts them at risk both inside and outside the classroom, as well as at emotional and psychological risk.

How institutional record systems are linked to citational practices becomes clear in a series of blog posts by Amy Dobrowolsky gathered in our archive. Dobrowolsky, a PhD student in urban studies and a librarian, maps the ways in which bibliographical systems which support citation (such as the creation and maintenance of library records) leave trans scholars vulnerable to outing. Dobrowolsky describes her experience of looking for a library record for a trans author in order to construct a citation, with the search revealing the author's former name within the library record (Dobrowolsky, 2013a). Trans people tend to be careful about revealing what they commonly refer to as deadnames, and trans communities generally consider deadnaming-exposing someone's previous name without permission - to be a form of profound violation (American Trans Man, 2012; Dobrowolsky, 2014; Spade, 2012). Dobrowolsky condemns the deadnaming violence inherent in traditional bibliographical practices: "I say violence because our old names are often weaponized against us" (Dobrowolsky, 2013b). Dobrowolsky's account confirms how trans erasure is inherent in these systems, which imagine neither the possibility of trans authors, nor that trans authors may require adjusted bibliographical practices, nor do they understand the implications of current practice for trans authors, implications which include the potential for violence.

Elsewhere, Dobrowolsky (2013c) describes how she was able to have her Library of Congress author record changed in a way that satisfies her own need to be known by her current name while preserving bibliographical links to previous work. She observes that, in doing so, she is able to gain at least some control over how she exists within such records, while also pointing out that she was able to do so because she is a librarian who understands these systems, something which other trans authors might not know. In other words, even if on a micro scale Dobrowolsky is able to make cisnormative bibliographical systems work for her, their inherent problems remain on a macro scale. Overall, she reveals the degree to which bibliographical and citational systems are not neutral; rather, they are social systems which serve social purposes, and must be re-conceptualized in light of information emerging through the perspective of trans scholars.

\section{Part II. Citation and author identities in TSQ}

In Part I we suggested that not only do trans studies scholars voice unique concerns related to gender and citation, they also reflect the practices of a community of care in their choices of citation. Part of these practices is to ensure that trans scholars and trans experience are cited over cisgender scholars and cisgender experience. In addition, these practices also include careful consideration of how exactly to characterize scholars who are trans, and how to vary that characterization for different audiences. In this way trans studies, as a multi-disciplinary, transnational, emerging field, seems to be developing its own community norms when it comes to relating new claims to preceding work. We wonder, though, do the norms and concerns that are evident in the above public statements also manifest themselves on the surface level of citation in the research article? Can practices of care-and the complex navigation between erasure and outing-be seen in the language used when trans scholars cite each other? If so, or if not, what lessons do these practices of citation hold for questions of gender and research writing more generally?

The corpus for this part of our analysis has been collected from TSQ: Transgender Studies Quarterly, the first dedicated trans studies journal in North America. TSQ began publication in 2014 under co-editorship of Susan Stryker and Paisley Currah. With their editorial care it has become more than a research journal: it is a site of community for scholars in trans studies. As the description of the journal clearly states, authors' shared, activist goal is contesting "the objectification, pathologization, and exoticization of transgender lives" along with the aim of addressing questions of gender and sex diversity in a way that feminist and queer scholarship has not adequately done ("TSQ" n.d.). The journal aims to create "vigorous conversation among scholars, artists, activists" and to examine how "'transgender' comes into play as a category, a process, a social assemblage, an increasingly intelligible gender identity" ("TSQ," n.d.). The fact that articles in the journal present a range of research methods and writing styles is a sign of trans studies as an emerging rather than consolidated field, with authors writing from various institutional and disciplinary positions in the humanities and social sciences (including educational studies, social history, sociology, anthropology, psychology, literary studies, and philosophy). In mixing materials, methods, and strategies, this journal also destabilizes established disciplinary boundaries in the process of summoning a new interdisciplinary community of trans studies activists and scholars who may question the limitations of the disciplines in which they were trained.

Our corpus spans the seven issues from TSQ's second issue in 2014 to the one most recently published at the time of this writing. We collected the first and the third research article of each issue, to a sum of 14 articles. Our analysis of these articles focusses on how integrally cited authors and research participants are introduced and positioned. Using Nvivo, we coded all integral citations in these articles, distinguishing between those that included reference to the cited author's identity and those that did not; we also identified all instances where article authors either brought up aspects of their own identity or described their relation to research participants or cited authors. ${ }^{1}$

\footnotetext{
1 Thanks go to Danica Verhoeve for expert coding assistance.
} 


\subsection{Integral citation}

Integral citations are moments when cited authors are named in the citing sentence, rather than exclusively referenced in parentheses or footnotes (Swales, 1990, p. 148). Research in applied language studies has revealed that the presence of integral citation differs significantly between disciplines (Fløttum, Gedde-Dahl, \& Kinn, 2006). We know that naming authors in a sentence happens through typical phrases and is thus linked to choices about stylistic variation between sentences (Charles, 2006). Examples of integral citation in our corpus include "According to Mary Douglas (1966)," or "As Gayatri Chakravorty Spivak argues," or "Yet, as David Valentine shows." We also know that while individual authors describe a variety of strategies when asked how they decide to cite integrally, in many instances they are unaware why exactly they include a certain author's name (Harwood, 2008). In other words, while integral citation patterns are established through practice in one's particular field and thus have shared disciplinary strategies underlying them, they are also "necessarily subjective and arbitrary" (Cronin, 2005, p. 72), and can be so "private, subjective, and opaque" that text analysis alone cannot explain what motivated them (Harwood, 2008, p. 1010). At the same time, there is evidence that integral citation may be used explicitly by authors to make visible authors and work often marginalised in contemporary academia (Hewings, Lillis, \& Vladimirou, 2010; Lillis, Hewings, Vladimirou, \& Curry, 2010). Scholars who have social justice agendas might therefore be expected to attempt to shape the composition of their scholarly community by deliberately bringing certain types of authors to the forefront-making space for them-while relegating those who represent privileged identities to the sidelines of the discussion.

By naming cited authors inside the sentence, researchers gain the opportunity of adding modifying and evaluating phrases to the author's name-phrases that can provide carefully chosen information to contextualize the points and concepts that are being cited or paraphrased. Such contextual information can be about the disciplinary identity of the author (from our corpus: "historian Joanne Meyerowitz," "queer studies critic Eve Kosofsky Sedgwick") or can contain other relevant autobiographical characterizations (from our corpus: “trans women like Tista," “activists Kaveri Indira Rajaraman and Gee Ameena Suleiman”). Modifiers can also be used to provide evaluation of the place that this author's work occupies in relation to others, a move that can be used for canonizing and counter-canonizing purposes (from our corpus: "leading DS + R critic Ed Dimendberg," "pioneering trans theorist Sandy Stone”). When we embarked on this corpus analysis, we expected that for authors working in trans studies, integral citation would be a key moment to highlight aspects of identity of the cited authors, including gendered identity. With the field's emphasis on first-person authority (Bettcher, 2009) and respect for the details of trans lives in the process of theorizing (Namaste, 2000), authors' inclusion of their own, particularly gendered experience in their research constitutes an important aspect of the quality of their knowledge-making. Autoethnography-of varying depths and lengths-is a common element in the writing of trans scholars (Macdonald, 2013). Considering this close relationship between an author's experience or positionality and the quality of their knowledge-making, it could be expected that identity markers that are made explicit in the cited work are likely to be carried over into an integral citation.

Table 1

Number of Integral Named Authors Per Article.

(articles listed by authors‘ disciplinary affiliation).

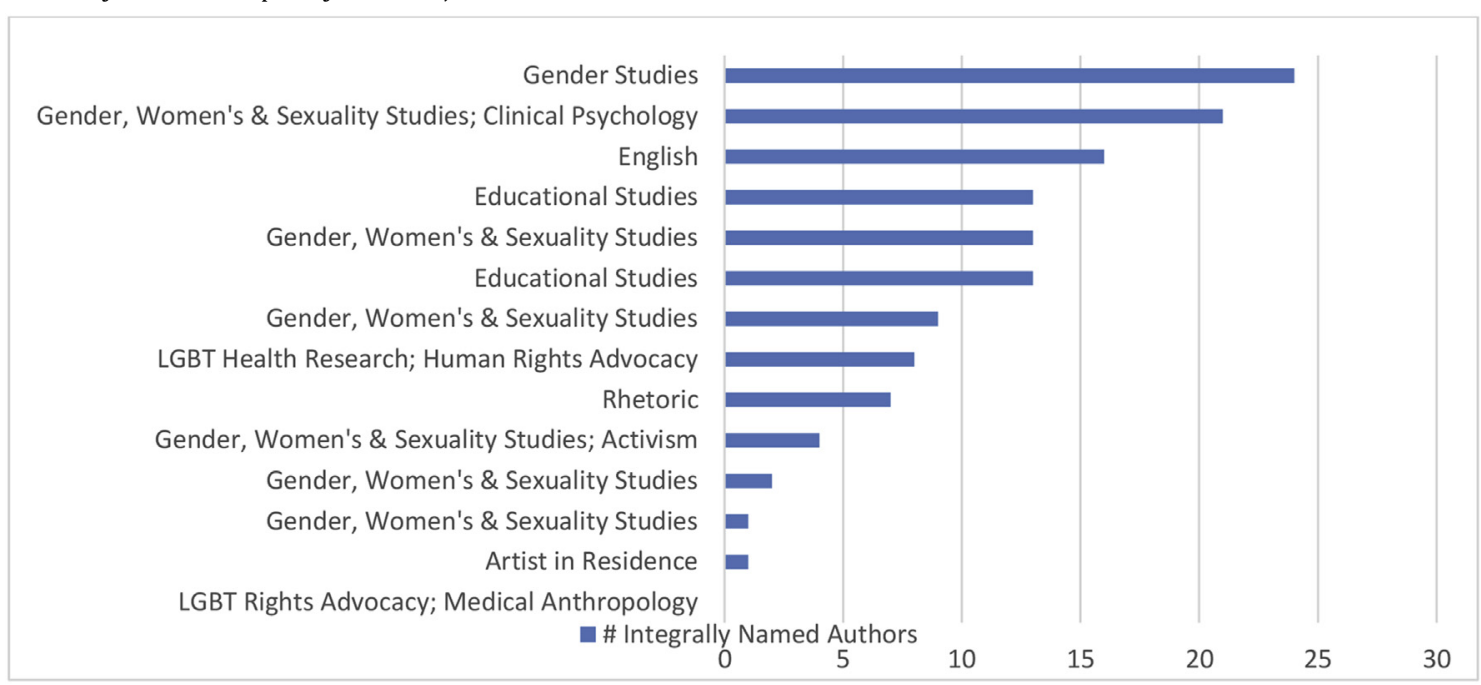




\subsection{Integral citation in the corpus of TSQ}

In our corpus of 14 articles, integral citation of unique authors (i.e., not counting when the same author is named more than once in the same article) $)^{2}$ ranged from 0 to 1 integrally named author (one of our articles had 0 , and two had 1 author integrally named; see Table 1) to 24 integrally named authors, with an average of 9.4 unique integrally cited authors per article. As Table 1 shows, the differences in integral citation did not obviously follow disciplinary distinctions. In an emerging multi-disciplinary field like trans studies, they seem to be an indication of the diversity of research projects and approaches. Trans Studies Quarterly invites the publication of projects that range in their use of materials-from pieces that reflect on trans activism, to those that analyze one type of primary data, to those that interweave methods of analysis and reference a range of scholarship. Of the 132 instances of unique integral authors across all 14 articles, we found 12 instances (or 9.1\%) where authors are identified as being trans. These 12 are only a portion of the trans authors integrally cited in these articles. In other words, the majority of scholars who are part of a transgender community-often centrally so-are not always identified as such when their work is integrally cited. For readers who don't know about these scholars' trans identities, the scholarship cited becomes less personal, less attached to the scholar's identity, and in the process the claims cited turn into more impersonal, more abstract knowledge statements. These statements thus become detached from their makers even as their authors' names retain an integral role in the sentence; they are even further detached where citation is non-integral.

Let us look more closely at the 12 instances of integral citation which identify trans authors:

1. In this period, "transgender" was used sporadically by particular activists such as Tista Das, one of the first trans women in West Bengal to undergo modern "sex change" or gender-affirmation surgery, as distinct from hijra castrationpenectomy (Das 2009). (Dutta \& Roy, 2014)

2. For Stryker, transsexuality was an extension of BDSM's experimentation into the wider world (Crawford, 2014)

3. Spade (2006) argues that the ways he was "different" as a child, including being Christian and on welfare, were neither more nor less relevant to his transgender identity than were his surgical or childhood behavioral histories: "Why should I engage this idea that my gender performance has been my most important difference in my life? It hasn't, and I can't separate it from the class, race, and parentage variables through which it was mediated" (319). (Labuski \& KeoMeier, 2015)

4. This concept can produce what pioneering trans theorist Sandy Stone calls a "bumptious heteroglossia" of transgender speech-acts and effects ([1991] 2006: 230). (Singer, 2015)

5. For Stryker, the transsexual body is a material expression of ambiguity and a point of dislocated, transformed, and contested gender identity, which refuses "human" and "sexual" natures as stable reference points. She makes clear the specifically nonhuman materiality of her body: "I find no shame ... in acknowledging my egalitarian relationship with non-human material Being; everything emerges from the same matrix of futures, narrows possibilities, and forecloses points of connection between human and nonhuman organic bodies." (Nurka, 2015)

6. Sandy Stone (2006: 231) has argued, transsexual experience is far richer than the language of destinations and "passing" would suggest; Stone prefers instead to think through "the possibility of a life grounded in the intertextual possibilities of the transsexual body." (Nurka, 2015)

7. Hayward's eloquent work on the relationality of trans bodies to the bodies of starfish brings together a posthuman approach to animality and her own transsexed experience in order to conjure up a productive trans-special figuration that is able to better articulate trans as an effect that is hypostatic to the body, specifically as a type of regeneration. (Nurka, 2015)

8. Jamison Green (2004) discusses his personal transition into manhood and the legal, medical, and policy requirements of his biomedical transition process. (Catalano, 2015)

9. Van der Merwe had gender-reaffirming surgery in 1975 and shared her story with the public. Her journey to be a woman elicited positive feedback from the public at large, most arguably owing to her aspirations of marriage. (Theron \& Kgositau, 2015)

10. Liesl Theron, a cisgender woman, and her trans man partner Lex Kirsten were the founders of Gender DynamiX in 2005. (Theron \& Kgositau, 2015)

11. Tshepo Kgositau is a trans woman, originally from Botswana who now resides in South Africa. (Theron \& Kgositau, 2015)

12. Audrey Mbugua, a trans woman who extensively advocates and writes about the views of the misinformed public. (Theron \& Kgositau, 2015)

Of the 12 instances where authors are identified as trans, 9 are references to authors who have written extensively about their own experiences as trans persons. In some examples, there is a strong implication that cited authors' knowledge claims stem from experience of transness: in Example 2, Crawford only implies that Stryker is trans ("for Stryker, transsexuality ..."), but this is located within an in-depth discussion of Stryker's intensely autoethnographic article "Dungeon Intimacies: The

\footnotetext{
${ }^{2}$ We say "author" and include single-as well as multiple-authored works in this category.
} 
Poetics of Transsexual Sadomasochism" (Stryker, 2008) where Stryker's own transness is explicit; in Example 4, while "trans theorist" is a somewhat ambiguous modifier-it can describe a theorist who is either trans or studies transness (or both) - it comes immediately after a sentence that introduces the term transgender as "a particular self-defined category of personhood," thus strongly implying that Stone is both-which she is-a trans woman and a theorist of trans studies.

What is not visible from these integral citations but is clear in the original texts is that auto-ethnographically written experience functions not only as sources of evidence for and quality marker of these authors' knowledge-making on trans issues, but is also part of these authors' ongoing practices of being out and therefore explicitly counteracting erasure. In this way, autoethnography effectively signals that an author's transgender identity is available for reference by others, that it is safe to refer to this author as trans in other publications. We posit that such careful thinking underlies the above identifications of these integrally cited authors as trans people. In contrast, an author's passing reference to their trans identity, without autoethnographic detail, constitutes less of a signal that further reference is welcome. In the context of a community that takes care not to out its members against their wishes as a protection against the violence of a highly transphobic society, a passing reference will likely be taken as a momentary declaration confined to a particular readership, not an invitation for publication that lies outside the trans author's control. We believe these careful considerations of whether to out a cited source in one's publication underlie the low number of explicit identification of some authors as trans.

Our corpus has only two instances where particular authors are integrally identified as cisgender. Both cases are selfreferences:

1. Liesl Theron, a cisgender woman, and her trans man partner Lex Kirsten were the founders of Gender DynamiX in 2005. (Theron \& Kgositau, 2015)

2. My status as a White, upper-middle-class, cisgender, nondisabled, and native English-speaking academic from a nearby prestigious university marked my privilege (Woolley, 2015).

This very limited use of the term cisgender-here used exclusively in relation to the article authors themselves-further underscores the practices of care around gender identification that we argue are underlying citation in trans scholarship. In our corpus, the category of cisgender appears to be, like the category of transgender, not something that is imposed on other authors unless they make this identification an explicit part of their scholarship.

\section{Conclusion: negotiating embodied knowledge and disembodied citation}

Members of the trans studies community are in the process of developing an ethics of citation that takes into account that an author might accept to be characterized in a certain way within one community, while in another experiencing that same characterization as a problematic or violent act. ${ }^{3}$ We can see traces of this ethics in the way in which citing writers withhold or include identity terms as they are citing others. As analysts who have not asked authors about their motivations, we cannot be sure about the citing authors' reasoning behind their integral citations. However, by combining analysis of scholars' perspectives on citation with analysis of actual textual practices we can begin to explore the values underpinning trans scholars' citation practices which can be characterised by an ethics of care.

Citation is a process that disembodies knowledge. Identities that may be considered important to authors and researchers remain hidden. Though integral citation might keep traces of the cited author's identity (in the form of names, pronouns, modifiers), the embodied nature of identities, particularly in trans research, the focus of this article, is often bracketed off from citation. While trans scholars pursue paradigm-shifting agendas in their autoethnographic studies, the ties these studies create between knowledge and trans researchers' and trans participants' bodies are muted if not lost in subsequent lines of citation. We note, however, that while these ties often become invisible on the textual surface of citation, the nature of this knowledge can nevertheless be present in the gestures of scholarly care that trans studies researchers and participants extend to each other. These gestures can be the difference between whom to cite and whom not to cite, whom to introduce with modifiers that mark their identity and whose identity to guard from one's readers, when to cite someone else's personal and intimate experience and when to protect that experience from circulating in potentially damaging ways.

Integral citation as form is, in the words of applied language scholar Janet Giltrow, "the tip of the iceberg, the visible part" while "the mass is underwater, in the unspoken silence of mutual consciousness" (Giltrow, 2016, p. 209). Giltrow notes that while the formal features of a genre can appear stable, that stability conceals a "submerged silence [that] is not only unfathomable but also unstable: composed of multiple consciousnesses able only to estimate rather than ascertain one another, and also liable themselves to change." In the case of our corpus study, the visible form of citation is stable, appears unchanging: integral citation in TSQ looks hardly different than in other disciplinary journals. But, as we have shown in Part I, more is hidden under that unchanging surface. A different consciousness can lie underneath citational form in trans studies than lies underneath the same form in other fields. In other words, conventional citational form seems able to contain but does not always make visible trans scholars' deliberate efforts to shift authority and to create new practices of care among an emerging community of scholars.

\footnotetext{
${ }^{3}$ To reference just one recent example of such violent identification, consider the shaming comments Milo Yiannopoulos made to his right-wing audience as he named and showed images of an outspoken trans student at the University of Wisconsin, Milwaukee (Landsbaum, 2016).
} 
In this article, we have put forward the concept of a scholarly community of care to help conceptualize the relationships and ethical concerns that underlie practices of integral citation in the field of trans studies. A scholarly community of care is built through relations that help sustain marginalized scholars' ability to work within dominant systems. Of course, the concept of the scholarly community of care can be applied beyond citation; it is a concept that can include the wide range of caring gestures and life-sustaining practices that marginalized scholars extend to each other in professional settings. One aspect of building a scholarly community of care that affects citation is the principle of giving more space to the voices and work of marginalized researchers: the effort to more deliberately include them and their work in teaching materials, in invitations to talks and panels, in reading lists for research projects, in references during presentations, in work cited lists of publications. As our discussion in Part I-the rich context provided by our archive of trans scholars' public statements on citation-has shown, such promiscuous referencing and citing is indeed what several of trans scholars urge we should do.

However, in the process of making the work of trans scholars more visible-thereby counteracting the erasure they frequently experience-the authors in our archive caution against the unwanted outing of trans scholars. In Part II-our analysis of integral citation in a corpus of research articles from TSQ: Trans Studies Quarterly-we explored how concerns related to erasure and unwanted outing might underlie trans studies scholars' choices in introducing integrally cited authors in research articles. In a field whose research methods have been shaped by trans people's first-person authority over their gender, by emphasis on the embodied nature of trans knowledge, and by the resulting importance of autoethnography, we might expect frequent reference to a cited author's trans identity. However, respect for unwanted outing and undesired characterizing of someone else's gender tempers such references and the use of identity-focused modifiers walks a fine line between counteracting erasure and producing unwanted outing. In our corpus analysis, we tentatively identify a pattern where the referencing of trans scholars' trans identity is dependent on those scholars having publicly written about their trans experience.

To end with a practical note, our paper points to several questions that could usefully be raised with students and scholars about citation practices in general, built on an ethics of care.

1. Choosing to characterize another's identity is a public act. On what basis should we characterize someone's identity?

2. Should the identity-marking modifiers we use come from the cited author's own writing, and/or should they be grounded in social knowledge of the cited author?

3. How can we avoid unwanted identity categories being imposed?

Such questions problematize citation as a normative value-free writing practice and point to the need to debate the premises on which we engage in citation, and ultimately, build more open knowledge communities.

\section{Acknowledgements}

The authors would like to thank the editors of this special issue, Theresa Lillis, Jackie Tuck, and Jenny McMullan, for the enthusiasm they have shown for this research, and for their unflagging assistance in shaping the finished paper. We are also grateful to organizers and participants at the 2017 Lavender Languages and Linguistics 24 (Nottingham, UK) and the 2017 Conference on College Composition and Communication (Portland, US) where we presented earlier versions of this work. Thanks go to Danica Verhoeve for expert coding assistance. Finally, Mary Ann S. Saunders is grateful to Katja Thieme for envisioning research possibilities at the intersection of trans studies and writing and discourse studies.

\section{References}

Adams, Faughn (2015). Transgender students deserve equal access. The Chronicle of Higher Education. https://www.chronicle.com/article/TransgenderStudents-Deserve/233755. (Accessed 23 January 2016).

Ahmed, Sara (2006). Queer phenomenology: Orientations, objects, others. Durham, UK: Duke University Press.

Ahmed, Sara (2014). White men. feministkilljoys. https://feministkilljoys.com/2014/11/04/white-men/. (Accessed 2 May 2016).

Ahmed, Sara (2015). Feminist shelters. feministkilljoys. https://feministkilljoys.com/2015/12/30/feminist-shelters/. (Accessed 1 October 2016).

Ahmed, Sara (2017). Living a feminist life. Durham, UK: Duke University Press.

American Trans Man. (2012). 14 reasons why it's not okay to out someone as trans-a public service announcement from your friendly, neighborhood trans person. American Trans Man. http://americantransman.com/2012/04/18/14-reasons-why-its-not-okay-to-out-someone-as-trans-a-public-serviceannouncement-from-your-friendly-neighborhood-trans-person/. (Accessed 11 December 2015).

Aultman, B. (2014). Cisgender. TSQ, 1, 61-62.

Beemyn, Genny (2015). Leaving no trans college student behind. The Chronicle of Higher Education. http://chronicle.com/article/Leaving-No-Trans-College/ 233754. (Accessed 23 January 2016).

Bettcher, Talia Mae (2009). Trans identities and first-person authority. In Laurie J. Shrage (Ed.), "You've Changed": Sex reassignment and personal identity (pp. 98-120). Oxford: Oxford University Press.

Bilodeau, Brent (2005). Beyond the gender binary: A case study of two transgender students at a midwestern research university. Journal of Gay \& Lesbian Issues in Education, 3, 29-44.

Bolivar, Daniela (2012). Community of care from a victim-perspective: A qualitative study. Contemporary Justice Review, 15, 17-37.

Catalano, D. Chase J. (2015). "Trans enough?" The pressures trans men negotiate in higher education. TSO, 2, 411-430.

Charles, Maggie (2006). Phraseological patterns in reporting clauses used in citation: A corpus-based study of theses in two disciplines. English for Specific Purposes, 25, 310-331.

Crawford, Lucas (2014). A transgender poetics of the high line park. TSQ 1, 482-500.

Cronin, Blaise (2005). The hand of science: Academic writing and its rewards. Lanham, MD: Scarecrow Press. 
Davenport, Elisabeth, \& Snyder, Herbert (1995). Who cites Women? Whom do Women cite?: an exploration of gender and scholarly citation in sociology. Journal of Documentation, 51, 404-410.

Dobrowolsky, Amy (2013). Bibliographic violence. The Urban Archivist. https://urbanarchives.wordpress.com/2013/03/13/bibliographic-violence/. (Accessed 11 December 2015).

Dobrowolsky, Amy (2013). Wikipedia's deadnaming violence. The Urban Archivist. https://urbanarchives.wordpress.com/2013/08/31/wikipediasdeadnaming-violence/. (Accessed 13 December 2015).

Dobrowolsky, Amy (2013). De-gendering \& reconceptualizing my well-known former name ... Now with LC authority! The Urban Archivist. https:// urbanarchives.wordpress.com/2013/02/04/de-gendering-reconceptualizing-my-well-known-former-name-now-with-lc-authority/. (Accessed 11 December 2015).

Dobrowolsky, Amy (2013). On digital discursive promiscuity. The Urban Archivist. https://urbanarchives.wordpress.com/2013/03/12/on-digital-discursivepromiscuity/. (Accessed 11 December 2015).

Dobrowolsky, Amy (2014). Words to deadname: Naming those who disrespect. Th'e Urban Archivist. https://urbanarchives.wordpress.com/2014/11/29/wordsto-deadname-naming-those-who-disrespect/. (Accessed 11 December 2015).

Drmay, Sidney (2016). Transitioning at rye: Why we need a new preferred name policy. The Eyeopener. https://theeyeopener.com/2016/09/transitioning-atrye/. (Accessed 1 October 2016).

Dutta, Aniruddha, \& Roy, Raina (2014). Decolonizing transgender in India some reflections. TSQ 1, 320-337.

Ellerbrock, Cheryl R., \& Kiefer, Sarah M. (2010). Creating a ninth-grade community of care. The Journal of Educational Research, $103,393-406$.

Enke, A. Finn (2013). The education of little cis: Cisgender and the discipline of opposing bodies. In Susan Stryker, \& Aren Z. Aizura (Eds.), The transgender studies reader 2 (pp. 234-237). New York, NY: Routledge.

van Enk, Anneke, \& Power, Kate (2017). What is a research article?: genre variability and data selection in genre research. Journal of English for Academic Purposes, 29, 1-11.

Epstein, Ronald M., Fiscella, Kevin, Lesser, Cara S., \& Stange, Kurt C. (2010). Why the nation needs a policy push on patient-centered health care. Health Affairs, 29, 1489-1495.

Fløttum, Kjersti, Gedde-Dahl, Trine, \& Kinn, Todd (2006). Academic Voices: Across languages and disciplines. Amsterdam; Philadelphia: J. Benjamins.

Giltrow, Janet (2016). Form alone: The supreme court of Canada reading historical treaties. In Natasha Artemeva, \& Aviva Freedman (Eds.), Genre studies around the Globe: Beyond the three traditions. Victoria, BC: Trafford Publishing.

Hager, Lisa (2015). In Welcoming trans academics (Inside Higher Ed). Accessed 10 September 2015. https://www.insidehighered.com/advice/2015/04/27/ essay-how-departments-and-conferences-can-welcome-transgender-academics. (Accessed 10 September 2015).

Halberstam, Jack (2011). The queer art of failure. Durham, UK: Duke University Press.

Harwood, Nigel (2008). Citers' use of citees' names: Findings from a qualitative interview-based study. Journal of the American Society for Information Science and Technology, 59, 1007-1011.

Hewings, Ann, Lillis, Theresa, \& Vladimirou, Dimitra (2010). Who's citing whose writings? A corpus based study of citations as interpersonal resource in English medium national and English medium international journals. Journal of English for Academic Purposes, Interpersonality, 9, 102-115.

Howard, Jennifer (2015). Colleges consider adopting inclusive language in their systems. The Chronicle of Higher Education. http://chronicle.com/article/ Colleges-Consider-Adopting-/233757. (Accessed 23 January 2016).

Hyland, Ken (1999). Academic attribution: Citation and the construction of disciplinary knowledge. Applied Linguistics, $20,341-367$.

Krum, Tiana E., Davis, Kyle S., \& Galupo, M. Paz (2013). Gender-inclusive housing preferences: A survey of college-aged transgender students. Journal of LGBT Youth, 10, 64-82.

Labuski, Christine, \& Keo-Meier, Colton (2015). The (Mis)Measure of trans. TSQ 2, 13-33.

Landsbaum, Claire (2016). Alt-right troll uses campus visit to openly mock a transgender student. The Cut. http://nymag.com/thecut/2016/12/miloyiannopoulos-harassed-a-trans-student-at-uw-milwaukee.html. (Accessed 2 February 2017).

Lillis, Theresa, Hewings, Ann, Vladimirou, Dimitra, \& Curry, Mary Jane (2010). The geolinguistics of English as an academic lingua franca: Citation practices across English-Medium national and English-Medium international journals. International Journal of Applied Linguistics, $20,111-135$.

Love, Heather (2010). Close but not deep: Literary ethics and the descriptive turn. New Literary History, 2, $371-391$.

Lutz, Catherine (1990). The erasure of Women's writing in sociocultural anthropology. American Ethnologist, 17, 611-627.

Macdonald, Joe (2013). An autoethnography of queer transmasculine femme incoherence and the ethics of trans research. In Norman K. Denzin (Ed.), 40th anniversary of studies in symbolic interaction, studies in symbolic interaction (pp. 129-152). Bingley, UK: Emerald Group Publishing.

Matsuda, Shayle (2015). Trans researchers are struggling to stay in science. That Has to Change. Wired https://www.wired.com/2015/12/science-needs-to-doa-better-supporting-trans-scientists/. (Accessed 1 October 2016).

McCold, Paul (2004). What is the role of community in restorative justice theory and practice? In Howard Zehr, \& Barb Toews (Eds.), Critical issues in restorative justice (pp. 155-172). Devon, UK: Criminal Justice Press and Willan.

McElhinny, Bonnie, Hols, Marijke, Holtzkener, Jeff, Unger, Susanne, \& Hicks, Claire (2003). Gender, publication and citation in sociolinguistics and linguistic anthropology: The construction of a scholarly canon. Language in Society, 32, 299-328.

Moreno, Ana I., \& Swales, John M. (2018). Strengthening move analysis methodology towards bridging the function-form gap. English for Specific Purposes, 50, 40-63.

Namaste, Viviane K. (2000). Invisible lives: The erasure of transsexual and transgendered people. Chicago, IL: University of Chicago Press.

Northedge, Andrew (2003). Rethinking teaching in the context of diversity. Teaching in Higher Education, 8, 17-32.

Nurka, Camille (2015). Animal techne transing posthumanism. TSQ, 2, 209-226.

Nygaard, L. P., \& Bahgat, K. (2018). What's in a number? How (and why) measuring research productivity in different ways changes the gender gap. Journal of English for Academic Purposes, 32, 67-79.

Owens, Lynn M., \& Ennis, Catherine D. (2005). The ethic of care in teaching: An overview of supportive literature. Quest, 57, 392-425.

Plett, Casey (2016). Zucker's "therapy" mourned almost exclusively by cis people. Harlot Media Accessed 13 April 2016 http://harlot.media/articles/2582/ zuckers-therapy-mourned-almost-exclusively-by-cis-people. (Accessed 13 April 2016).

Pryor, Jonathan T. (2015). Out in the classroom: Transgender student experiences at a large public university. Journal of College Student Development, 56, 440-455.

Rankin, Susan R. (2005). Campus climates for sexual minorities. New Directions for Student Services, 2005, 17-23.

Singer, T. Benjamin (2015). The profusion of things the "transgender matrix" and demographic imaginaries in US public health. TSQ 2, 58-76.

Spade, Dean (2010). Be professional! Harvard Journal on Legislation, 33, 71-84.

Spade, Dean (2012). Some very basic tips for making higher education more accessible to trans students and rethinking how we talk about gendered bodies. Radical Teacher, 92, 57-62.

Stone, Sandy (1991). The "empire" strikes back: A posttranssexual Manifesto. In Julia Epstein, \& Kristina Straub (Eds.), Body Guards: The cultural politics of gender ambiguity. New York; London: Routledge.

Stryker, Susan (1994). My words to victor Frankenstein above the village of Chamounix: Performing transgender rage. GLQ: A Journal of Lesbian and Gay Studies, 1, 237-254.

Stryker, Susan (2006). (De)subjugated knowledges: An introduction to transgender studies. In Susan Stryker, \& Stephen Whittle (Eds.), The transgender studies reader (pp. 1-17). New York: Routledge.

Stryker, Susan (2008). Dungeon intimacies: The Poetics of transsexual sadomasochism. Parallax, 14, 36-47.

Swales, John M. (1990). Genre analysis: English in academic and research settings. Cambridge, Eng.; New York: Cambridge University Press. 
The Social Justice Institute, University of British Columbia, n.d. Promoting Trans-Literacies-Supplementary Resource. http://grsj.arts.ubc.ca/get-involved/ promoting-trans-literacies/promoting-trans-literacies-supplementary-resource/ Accessed 10 December 2015.

Theron, Liesl, \& Kgositau, Tshepo Ricki (2015). The emergence of a grassroots african trans archive. TSQ, 2, 578-583.

Toutkoushian, Robert K. (1994). Using citations to measure sex discrimination in faculty salaries. The Review of Higher Education, $18,61-82$.

TSQ: Transgender Studies Quarterly, n.d. https://www.dukeupress.edu/TSQ-Transgender-Studies-Quarterly/ Accessed 18 June 2016.

Tuck, J. (2018). "I'm nobody's Mum in this University": the gendering of work around student writing in UK Higher Education. Journal of English for Academic Purposes, 32, 32-41.

Valentine, David (2012). Sue E. Generous: Toward a theory of non-transexuality. Feminist Studies, 38, $185-211$.

West, Jevin D., Jacquet, Jennifer, King, Molly M., Correll, Shelley J., \& Bergstrom, Carl T. (2013). The role of gender in scholarly authorship. PLoS One, 8, 1-6.

Wood, Riley, \& Drmay, Sidney (2016). Gender markers force some students to identify as something they are not. The Eyeopener. https://theeyeopener.com/ 2016/09/transitioning-at-rye-what-is-the-purpose-of-gender-markers/. (Accessed 1 October 2016).

Woolley, Susan W. (2015). "Boys over here, girls over there" a critical literacy of binary gender in schools. TSQ 2, 376-394. 